\title{
China and the BRICS Development Bank: Legitimacy and Multilateralism in South-South Cooperation
}

\author{
Adriana Erthal Abdenur*
}

\begin{abstract}
In 2013 the BRICS (Brazil, Russia, India, China and South Africa) grouping agreed to undertake what will, when implemented, become its most concrete project yet: the BRICS Development Bank (BDB). From the perspective of the Chinese government, which already leads a vast and far-reaching cooperation programme, the bank will not represent a significant addition to its cooperation portfolio. What, then, motivates China's participation in the initiative, and what can it bring to the table? This article analyses China's interests in the BDB in the light of its past experiences with development, at home and abroad. I argue that China's interests in backing the bank project are primarily political. In addition to offering a concrete opportunity to legitimise China's multilateralism strategy - burnishing China's image as a responsible yet pro-reform global player - the bank project also allows China to influence international development norms. At the same time, the project also poses challenges for China, especially in terms of promoting poverty alleviation without resorting to trickle-down assumptions about an infrastructure-focused approach to development.
\end{abstract}

\section{中国和金砖国家发展银行：南南合作的合理性及其多边主义 阿德里亚娜・厄瑟尔・阿卜杜努尔}

2013 年，“金砖” 国家巴西、俄罗斯、印度、中国和南非一致同意筹建金砖国家 发展银行, 这将是金砖国家最为具体的一个项目。中国主导了大量意义深远的合作 项目，在中国政府看来，发展银行算不上一个重大项目。那么中国为何要参与，该 项目又能起到什么作用？本文根据中国在国内外的发展经验，分析了建立金砖国家 发展银行能给中国带来的利益，指出中国支持该项目主要是出于政治方面的考虑。 该项目能使中国表明多边战略的合理性，展现中国负责任并且倾向改革的国家形 象，而且中国还能借此影响国际发展模式。同时，该项目也对中国提出挑战，特别 是在不借助以基础设施为主的发展的涓滴效应而进行扶贫方面。 


\section{Introduction ${ }^{1}$}

In 2013 the BRICS (Brazil, Russia, India, China and South Africa) grouping agreed to undertake what will, when implemented, become its most concrete project yet: a fully-fledged development bank. The initiative - part of the coalition's efforts to press for reform of global governance in international development - seeks to provide a multilateral institution that can offer developing countries access to capital for infrastructure and industrialisation projects without resorting to traditional institutions such as the World Bank. The BRICS also argue that the new organisation would better reflect the principles and practices of contemporary South-South cooperation. In addition to these joint objectives, in each of the individual BRICS, policy elites have their own set of motivations for backing the initiative.

Analysing these diverse interests is essential to understanding the key political struggles and alignments bound to emerge as the bank's design is negotiated and implemented.

For China, which already has a vast and farreaching cooperation programme, the BRICS Development Bank (here shortened to BDB) will not represent a significant addition to its cooperation portfolio, including in Africa, where China has been investing heavily for decades. What factors, then, drive China's participation in the BDB? And what substantive ideas and experiences does China bring to the initiative? This article analyses Chinese policymakers' key motivations and potential contributions by considering China's experiences in trying to foster development, both at home and abroad, and its cooperation diplomacy.

My main argument is that China's interests, in backing the BDB project, are primarily political. First, the bank project represents a concrete opportunity to legitimise China's multilateralism strategy, burnishing the image that the Chinese government has sought to convey of a responsible global player bent on reshaping rather than upending established institutions. Second, the initiative offers China a chance to influence the norms-setting process within the field of development, contesting efforts by the Development Assistance Committee (DAC) of the Organisation for Economic Co-operation and Development (OECD) to codify and promote the principles claimed by Northern donors. Finally, the bank project represents an opportunity for China to learn about the practices and principles adopted by other providers of South-South cooperation.

Politically, in pursuing these interests, China has to strike a careful balance. Precisely because China's economic weight and cooperation far surpass those of its fellow BRICS states - its GDP is larger than all of the other BRICS combined - boosting the legitimacy of the grouping as a multilateral platform requires China to maintain a somewhat discreet position. China's interests are likely to influence the bank through incremental negotiations rather than as an aggressive strategy, which could come across as off-putting to its fellow members and thus undermine the grouping's demands for a more horizontal global governance architecture.

In addition, in shaping the bank's orientation, China must work to create innovative linkages between two goals it has long championed: infrastructure and poverty alleviation. Rather than relying uncritically on trickle-down economics assumptions that infrastructure automatically begets broader economic and social benefits, China - and more broadly, the BRICS - must find innovative ways to mitigate negative impacts and spread the benefits of infrastructure more broadly. In other words, China must apply the lessons it has learned about the drawbacks of excessively focusing on economic growth as a proxy for development.

The article is structured as follows. After providing an overview of the BRICS and the development bank project, the text offers an analysis of China's experience and interests in the field of international development as they relate to the BDB. The last part of the article examines the implications of China's involvement in the project, as well as some of the initiative's broader repercussions for norms-setting within the field of development cooperation.

\section{The BRICS and the Development Bank project 2.1 The BRICS grouping}

The post-Cold War era has witnessed a proliferation of coalitions and informal multilateral platforms - some, like the G20, bringing together advanced and developing countries, and others geared specifically at South-South cooperation. Among the latter, the BRICS grouping is arguably the most visible initiative. The initially four-state coalition, 
bringing together Brazil, Russia, India and China under the acronym BRIC, emerged in 2006 at the initiative of Russian Foreign Minister Sergey Lavrov, and the first summit was held in Yekaterinburg, Russia on 16 June 2009. Since then, the heads of state have been meeting annually (with the 2011 entry of South Africa), with subsequent summits held in Brasília (2010), Sanya (2011), New Delhi (2012), and Durban (2013). The 2014 meeting is scheduled to take place in Fortaleza, Brazil.

The main impetus for the group's formation was a common interest in reforming (though not necessarily overhauling) the global governance architecture. At that juncture, the geographic spread and relative dynamism of these economies gave them unique leverage in pushing for change at a time when the international system was perceived to be in flux, with US hegemony cast into doubt. Policy elites in the BRICS have argued that, although certain developing economies had become key drivers of regional or global growth, the main organisations involved in global governance remain dominated by the few countries that set the rules after the Second World War. Despite the BRICS' economic, political, geographic and cultural heterogeneity, their leaderships share the desire to make the architecture more representative, at least in the sense of opening up more space for themselves. During the first two summits (2009 and 2010), the grouping focused heavily on the global economic crisis, which presented additional motivation for the coordination of efforts and resources. Over time, the coalition expanded its agenda, launching discussions in fields as disparate as development cooperation, technology, and political cooperation.

Despite the BRICS' combined economic and demographic relevance, the initiative has often been met with scepticism, particularly from the advanced economies, with some critics arguing that the five states are too heterogeneous to coordinate in any significant manner. This pessimism is fuelled in part by the BRICS' low level of institutionalisation: the grouping has no headquarters, no charter, no flag and no governance structure beyond the cycle of summits and meetings (Kahler 2013). Scepticism is also perpetuated by a tendency (by media and academics alike) to overemphasise the role of Goldman Sachs' economic projections in the grouping's formation - a point that tends to underestimate the BRICS' political dimension. Conversely, other analysts have declared the BRICS initiative as a fait accompli. According to this view, the BRICS represent a concrete, positive alternative to the current global system, pressing for much-needed reform and effectiveness while offering an alternative path to development that relies more heavily on state intervention. At the other end of the spectrum, alarmists portray the BRICS as a real menace to the existing order - a coalition bent on emptying the established regimes in favour of questionable practices and norms, including - within international development - the provision of 'rogue aid' (Naím 2007).

Instead, here the BRICS grouping is treated as a loose coalition embedded within networks of organisations of varying degrees of institutionalisation. In other words, in addition to being active members of the United Nations and the Bretton Woods Institutions, those five states participate concurrently in less formal platforms such as the G20, the India Brazil South Africa Dialogue Forum (IBSA) and the BRICS. The BRICS grouping is also a dynamic entity: within its short history, it has changed in both composition (with the entry of South Africa) and agenda. This dynamism contrasts with the inflexibility of established organisations and confers certain advantages to its members, because it allows them to engage in topic-specific dialogues and to cement ties informallyincluding by meeting at the margins of major international events - without committing to a rigid alliance. While the BRICS are a loose coalition, they are not improvised, addressing areas as disparate as collective security, financial governance and climate change as windows of opportunity emerge.

In addition to this flexibility, the grouping serves two key purposes for its members. First, coordinated positions within the grouping can be transposed to other multilateral settings, whether other loose coalitions or formal institutions. The 2013 eThekwini Declaration, for instance, states that the five members will join forces in implementing the International Monetary Fund (IMF) Governance and Quota Reform: 'We urge all members to take all necessary steps to achieve an agreement on the quota formula and complete the next general 
quota review by January 2014' (BRICS 2013). Second, the BRICS can serve as a platform for concrete initiatives, especially in areas considered to be the 'paths of least resistance' - topics in which the member states are likeliest to find common ground, maximising their chances of coordinated action. Where there are clear division lines - such as Security Council reform, where the BRICS are split between two $\mathrm{P} 5^{2}$ countries (Russia and China) and three members that aspire to hold permanent seats - such coordination remains a mid- to long-term project.

\subsection{The BRICS Development Bank project}

Among the perceived 'paths of least resistance', development financing is an area where the BRICS can realistically deepen cooperation: all five states want to expand South-South ties, both among themselves and with other developing countries. In addition, the BRICS states have backed this discourse with concrete resources, having substantially increased intraBRICS trade and investment over the past five years. ${ }^{3}$ More broadly, all five wish to reduce the dominance of the US dollar as the anchor currency for the global economy, although its exact replacement is not yet clear.

These common interests became evident by the fourth BRICS Summit, held in Durban in 2013, as the five heads of state agreed on a new development bank, a contingency reserve arrangement, a business council and a thinktank council. According to the eThekwini Declaration, the five countries' Ministers of Finance had been tasked in March 2012 with 'examin[ing] the feasibility and viability of setting up a New Development Bank [...] to supplement the existing efforts of multilateral and regional financial institutions for global growth and development' (BRICS 2013). Since then, the initiative has moved forward through a BRICS meeting held on the sidelines of the G20 meeting in Saint Petersburg, Russia and meetings of sherpas and ministerial representatives.

The bank, which is still being designed, is meant to address capital deficits for long-term financing for infrastructure and industrial projects in developing countries - including, as needed, the BRICS themselves. Russia has proposed a US $\$ 100$ billion equity base, with member states making equal initial contributions and having equal voting rights within the bank; at the time of writing, however, there are counterproposals that the amount depends on the size of each country's economy. Loans will most likely be offered at market rate, diminishing the influence of political considerations on the way in which the capital is used. ${ }^{4}$ Given the high visibility of Africa within the BRICS agenda so far - African development featured prominently at the Durban Summit - the bank is also intended to foster socioeconomic development on the continent, although its operations will not be exclusive to Africa.

The bank's institutional design and operations will depend on ongoing discussions among member states regarding credit lines, headquarters location, capital structure, governance, the bank's rating, and the criteria for determining which projects the bank will fund. Governance design covers not only how leadership is chosen, but also the institution's hiring practices and career tracks. Given how strongly the BRICS emphasise respect for national sovereignty, the bank is unlikely to impose political conditionalities on the loans it provides.

Due to the complexity of establishing the decision-making processes, it is unclear when the bank will become fully operational. In September 2013, at the G20 meeting in St Petersburg, Russian Deputy Finance Minister Sergei Storchak stated that 'we must assume that the bank will not start functioning as fast as one could imagine' (Caulderwood 2014). 'These discussions will be shaped by the interests of the BRICS countries, as well as their individual cooperation styles and priorities. While providing a full account of all five states' development cooperation programmes lies beyond the scope of this article (for a comparative analysis, see Mawdsley (2012)), it is worth noting some key characteristics that are relevant to the $\mathrm{BDB}$ project.

Although the Soviet Union was a major provider of development cooperation, after its 1991 collapse the Soviet programme was suddenly abandoned, and Russia was redefined as a recipient of aid. It was only in 2007, with the adoption of the 'Concept of Russia's Participation in International Development Assistance', that Moscow signalled its intention to become a net provider of cooperation. Russia's bilateral development cooperation is relatively limited, focusing on agriculture, energy, social 
programmes and disaster assistance within former Soviet states. However, as part of its foreign policy efforts to project Russia as a re-emerging state, the Russian government has worked to expand its initiatives abroad, including through expanded debt relief and a growing focus on Africa (Arkhangelskaya and Shubin 2013). Russia has also cooperated with international organisations in designing its cooperation policies, for instance aligning its accounting procedures with DAC standards and reporting its aid volumes to the OECD in 2011 (so far, the only BRICS to do so) (Bakalova and Spanger 2013). To Russia, whose cooperation is fragmented and marked by low institutionalisation, the BDB offers an opportunity to regain its footing in international cooperation.

To Brazil, South-South cooperation has served both to diversify the country's economic partnerships and to project influence abroad, particularly in South America and Africa. By building up expertise niches in areas like tropical agriculture, public health and education, Brazil has both expanded and institutionalised its official development cooperation, much of which is coordinated through the Brazilian Cooperation Agency (ABC), a division of the Ministry of External Relations. Brazil's largest construction companies undertake infrastructure projects abroad, often with financial backing from the Brazilian Development Bank (BNDES) (Cabral and Weinstock 2010). Non-state actors, including non-governmental organisations (NGOs) and labour unions, also carry out cooperation, either through or outside of official channels. To the Brazilian government, the BDB would serve to both project and legitimise Brazilian cooperation within a multilateral setting while boosting Brazil's calls for reform of global governance - a topic that has been particularly salient in Brazilian foreign policy since Luiz Inácio Lula da Silva's leftist presidency (2003-11). In addition, the bank would also help to enhance the reach of Brazilian cooperation at a time when the economy has slowed down and Brazil's South-South development initiatives suffer from scaled-back funding.

India's development cooperation has been led by non-state actors such as private firms and community organisations, but lately the Indian government has taken steps to increase the state's role. In 2012, it launched the
Development Partnership Administration (DPA) and new financing mechanisms for development cooperation (Raghavan 2013). The Indian Technical and Economic Cooperation (ITEG) programme, created in 1964, has decades of experience in capacity-building, and the India Development Initiative (IDI), established in 2003, has cancelled the debts of several heavily indebted partners. Geographically, India's official cooperation focuses on its geographic vicinity, where not only does it have important economic interests, but also faces significant security concerns and geopolitical competition. While India has participated in OECD-led discussions about aid and cooperation, its government has expressed reservations about the DAC's use of political conditionalities. Indian official development cooperation has expanded over the past decade, but its own access to foreign capital sources is limited, meaning India's interest in providing finance may waiver depending on the domestic political situation (parliamentary elections are scheduled for 2014).

During apartheid, South Africa's development assistance was allocated to its nominally autonomous homelands. Since 1994, South African cooperation abroad has expanded, especially in Africa. South African firms, especially in telecommunications and retail, have driven economic cooperation, while the state's role has concentrated in peacekeeping, electoral reform and post-conflict reconstruction (Vickers 2012). Despite relying on a more restricted budget than fellow BRICS states, the South African government has worked to formalise and coordinate the country's cooperation through the creation of the South African International Development Agency (SAIDA), later renamed the South African Development Partnership Agency (SAPDA). There is some concern that South African firms operating elsewhere in Africa will suffer with increasing competition from other cooperation providers, including the other BRICS (Besharati 2013). On the other hand, the BDB would allow South Africa to strengthen its position as a gateway to African development.

As for China, its cooperation-related interests both align and compete with those of fellow BRICS. The speed of China's expansion abroad means that it increasingly operates in the same countries - sometimes, the same sectors - as 
other South-South cooperation providers. For instance, in 2013 China recently announced a US\$125 million fund, the China-Lusophone Africa Development Fund, meant to help Chinese companies enter Portuguese-speaking markets in Africa (Ventures Africa 2013). The fund also boosts competition for Brazilian oil and construction companies operating in countries like Angola and Mozambique. In addition, China occasionally vies for the same projects as fellow BRICS countries, with the capacity to outbid them. In South Africa, Russia and China are vying for a massive nuclear energy tender. Although there are other dynamics of competition among the BRICS, the size and agility of Chinese cooperation means that the other BRICS countries view it as a source of growing competition. While Chinese companies are interested in enhancing their competitiveness, as analysed in greater detail in the next section of this article, the government has tried to attenuate the perception of China as an aggressive player for which collaborative action through the BDB can prove extremely useful.

At any rate, inter-member competition does not necessarily pose a significant hurdle to the creation of the BRICS Development Bank. The major contributors to the World Bank, after all, also compete among themselves, as do those of regional banks such as the Asian Development Bank. In addition, the bank initiative serves common political goals. By creating a development bank from scratch, the BRICS can pressure existing institutions for faster reform while offering a concrete alternative to the Bretton Woods Institutions. As one BRICS diplomat put it, 'If the World Bank doesn't want to reform in earnest, we'll just go ahead and create our own bank.' Finally, the bank legitimises the grouping by allowing member states to prove their (frequently questioned) capacity to launch concrete initiatives. All of the BRICS have resisted (albeit to different degrees) efforts by the DAC to promote principles dear to Northern donors, and the bank potentially represents a platform through which to establish a new normative framework.

\subsection{China and the BRICS}

For China, the BRICIS grouping offers a series of benefits and potential opportunities, many of which overlap with those of the other member states. First, this trans-regional initiative allows
China to boost its multilateralism, participating in a wider variety of debates of global reach. Second, the BRICS provides China with the chance to reinforce its claim that it is a responsible, solitary global player. Third, the BRICS allows China to strengthen its dual identity as both a developing country dedicated to South-South cooperation, and a rising power striving for governance reform. Finally, because intra-BRICS relations have deepened, the grouping is a way for China to increase trade and investment ties to other regional powers and to become a more influential player in global debates about how international development ought to be tackled.

Although, as a permanent seat holder at the UN Security Council (UNSC), China - like Russia has behaved more conservatively than the remaining BRICS where matters of security architecture reform are concerned, in other areas of global governance China has long called for greater inclusiveness, often claiming to advocate on behalf of other developing countries. Through the BRICI, China can reinforce these calls for change without coming across as overly aggressive. The balance that China tries to strike between change and status quo maintenance on issues of development is reflected in a 2012 speech by Hu Jintao:

In their co-operation, BRICS countries have committed to promoting South-South cooperation and North-South dialogue, endeavouring to implement the United Nations Millennium Development Goals, working for early realisation of the goals set out in the mandate for the Doha development round negotiations, striving to secure a greater say for developing countries in global economic governance, and fighting all forms of protectionism (Radebe 2012).

From a geopolitical point of view, the BRICS helps China to counter US hegemony without direct confrontation. In addition, the grouping allows China to learn more about, and deepen ties with other rising powers - a particularly important goal given the global reach of Chinese interests. The desire to strengthen alignments and relations with such states helps to explain China's concerted efforts to bring South Africa into the grouping - a move reflective of China's strong interests in Africa and its view of South 
Africa as a gateway to the rest of the continent (He 2011). By boosting the BRICS, China has also been able to deflate the IBSA, a

South-South initiative that, because it is premised on the common identity of its three members as diverse, democratic rising powers, excludes the possibility of Chinese membership.

To help consolidate the BRICS, China has remained active at summits, ministerial reunions, and sherpa meetings. The importance attached by China to the BRICS within its multilateral strategy is reflected in the 2012 work report of the 18th Chinese Communist Party congress, which set guidelines for China's grand strategy in the coming years. Within the document, only the UN, the G20, the BRICS and the Shanghai Cooperation Organisation (SCO) are mentioned among China's institutional priorities (Zhao 2013). China has also shown some initiative in proposing ways to increase the grouping's degree of institutionalisation. For instance, one of China's top diplomats has recently suggested the creation of a common BRICS secretariat (Wright 2013). At the same time, in order to reap the benefits of its membership in the grouping, China has so far consciously adopted a strategy of relative discretion within the BRICS, avoiding a stance that could be interpreted as domineering.

China's discreet behaviour within the BRICS, however, does not mean that it will refrain from influencing the bank's design. Like the other BRICS states, China has appointed a task force led by a senior official with substantial experience to lead its work on the BDB: Chen Yuan, who in April 2013 stepped down as Chairman of the China Development Bank (CDB). Under Yuan, the $\mathrm{CDB}$ reduced its non-performing loan ratio and depoliticised the CDB's lending process by creating a system that increases autonomy between credit risk assessments and loan approval (Provaggi 2013). The government's appointment of Yuan to lead its BDB task force reflects the level of importance attached to the initiative.

\section{Chinese development and its institutions}

What kinds of ideas is China likely to bring to the BDB? In this section, I provide an overview of how China's development model has changed across time, as well as how its experiences at home are linked with its initiatives in international cooperation.

\subsection{Chinese development: a shifting model}

In the 1950s, despite the generally inward policy orientation of Mao Zedong, the People's Republic of China (PRC) began providing development cooperation: it transferred goods to Pyongyang after the Korean War and offered development finance to socialist countries along its border. Shortly afterwards, at the initiative of Premier Zhou Enlai, China also began assisting liberation movements in Africa, increasing this cooperation as African colonies became independent states. In the 1960s, Zhou led efforts to lay out the basic principles of the Chinese development cooperation. In 1964, he introduced the 'Eight Principles of Economic and Technical Assistance', which included mutual benefit, respect for national sovereignty, and helping partner countries to become more selfsufficient. By 1973, China was providing development assistance to 30 nations in Africa alone (Strange, Parks, Tierney, Fuchs, Dreher and Ramachandran 2013) - a diversification that helped the PRG to replace Taiwan in the United Nations, obtaining a permanent seat at the Security Council. However, with the notable exception of the TAZARA railway, built in the 1970s to link the Tanzanian port of Dar es Salaam to Zambia's Central Province, China's initiatives during this period were mostly scattered or small-scale.

Under Deng Xiaoping, economic liberalisation began in the countryside and then accelerated with the establishment of special economic zones (SEZs) designed to gradually foment investment and technology transfer. Investment in largescale infrastructure, including dams, roads and railways, ports, industrial complexes and urban equipment, helped to fuel the growth of stateowned enterprises (SOEs), but later the government also sought to expand the private sector (Naughton 2007). These policies yielded high and sustained economic growth - China attained double-digit GDP growth rates for over 15 years - and they strengthened the PRC's poverty alleviation capacity, lifting an estimated 600 million citizens out of poverty (Gallagher 2013). Political liberalisation, in contrast, was put on hold after the 1989 Tiananmen crackdown in Beijing. Since then, China's rapid growth has brought about new challenges, including deep cultural shifts, serious environmental degradation and new forms of social inequality, including a large 'floating' 
migrant population alongside emerging pockets of prosperity in urban areas.

China's rapid transformation also caused significant shifts in China's role in international development cooperation. According to Chin (2012: 584), China went from being a net donor and receiving virtually no official development assistance (ODA) from the DAC countries to being the world's largest ODA recipient just a few years later. In 1999 China graduated to the International Development Association (IDA), then reverted to zero net ODA as net loan repayments offset ongoing grant transfers before attaining net donor status.

Against this dynamic backdrop, China's experience with development financing begins with the state institutions created to foment domestic investment, including key policy banks like the CDB and the China EximBank (CEB). The CDB, created through the 1994 Policy Banks Law to provide loans for major infrastructure projects, became responsible for much of the financing for several mega-projects, including the Three Gorges Dam and Shanghai Pudong International Airport, China's busiest international hub. The GDB, which describes itself as 'the engine that powers the national government's economic development policies' (China Development Bank n.d.), maintains deep ties to the state, as reflected in the bank's governance structure: it is led by a cabinet minister level governor, under the direct jurisdiction of China's State Council. The ensuing projects have fomented considerable prosperity in China, but they have also entailed major population dislocation, environmental degradation, and in many cases, social protests.

China's development financing institutions have changed across time as China's development model was modified and as Chinese interests abroad expanded. The country's fast-paced economic growth demanded raw inputs for its manufacturing sector and for the changing lifestyle of its swelling, increasingly urbanised middle classes. The Chinese government played an active role in opening doors abroad, backing the internationalisation of Chinese companies especially SOEs - and fomenting international trade and investment (immediately after the Tiananmen crackdown, it also sought to overcome the relative isolation in which China found itself internationally). Through high-level visits and other exchanges, as well as the expansion of China's diplomatic representations abroad, the government deepened ties with other developing countries, prioritising providers of minerals, timber and other commodities. China's energy security policy, which has sought to diversify sources beyond the Gulf suppliers, has also provided impetus for expanded South-South ties.

These efforts have been accompanied by a discourse stressing horizontality, mutual benefit and lack of conditionalities (save for the requirement that partners refuse to recognise Taiwan, in keeping with Beijing's One China policy). The State Council's 2013 White Paper China-Africa Economic and Trade Cooperation reaffirms Zhou Enlai's Eight Principles (Office of the State Council 2013). China has also leveraged its identity as a developing country, framing its cooperation as unburdened by the colonial legacy of Northern aid. Finally, to counter perceptions of China as a threat, the Chinese government stressed the idea of a 'peaceful rise', later changed to 'peaceful development', according to which China's fundamental interests are international peace and prosperity, both essential to its paramount goal of socioeconomic development. This discourse is coupled with a soft power strategy anchored in diplomatic, cultural and education exchanges, as well as strategic grants and soft-loans, meant to mitigate frictions. As part of this effort, in 2012 the Chinese government urged Chinese civil society entities to forge closer ties to their African counterparts (Meng and Sun 2013). However, beyond thinktank meetings the scope and substance of these initiatives are unclear and Chinese cooperation remains heavily state and company-led.

In financially backing the internationalisation of Chinese firms, the state has relied on the same institutions that guided its domestic investments. Many Chinese projects abroad - often in markets long overlooked by Northern countries - have generated strong profits for SOEs and private sector firms, encouraging even more Chinese companies to go abroad. Over the past decade, the Chinese government has continued to emphasise the intersection of aid, trade, and investment, while complementing market-rate loans with concessionary loans, grants and debt forgiveness. In Africa, China has also promoted the creation of SEZs, thus adapting components 
of its pioneering experiments at home to other contexts (without trying to replicate its development model wholesale).

This intensifying cooperation has taken place within the broader context of deep changes within the field of international development as South-South cooperation providers gained influence relative to OECD donors. While, like China, most of the developing countries have been offering cooperation for decades, after the millennium, in part due to the commodities boom, they gained the economic leverage to significantly expand their cooperation initiatives. This diversification of actors within international development accelerated after the 2008 onset of the global economic crisis, when many advanced countries scaled back their aid programmes. In contrast, some rising powers proved resilient to the initial shock of the crisis and were able to deepen their South-South ties, including in countries where Northern aid shrank (OECD 2012). Within this shifting landscape, China has played a highly visible role due to the size and visibility of its cooperation, the pace of its expansion, its unwillingness to adhere to the DAC's norm-setting efforts, and its reluctance, when compared to other South-South providers, to engage in trilateral cooperation with Northern donors.

Key Chinese banks have also gained visibility for helping to finance much of this expansion. In 1995, aid reform allowed those institutions to develop a variety of credit lines and grants, as well as a resource-credit swap model in which loans are repaid in local products and primary goods. Just as they financed major infrastructure and industrial policy projects in China, abroad these mechanisms are used for the same kinds of initiatives. Compared with other providers of development financing, Chinese banks and companies actively sought out sectors with promising rather than proven growth potential, showing greater willingness to accept risks than their Western counterparts (Provaggi 2013).

Rather than being organised under a single coordinating agency, those institutions are part of a wide array of ministries, divisions and agencies involved in different (and sometimes overlapping) aspects of cooperation. The State Council sets government policy for cooperation, determines the annual development assistance budget and reviews large grants (Brautigam
2009). The Ministry of Commerce (MOFCOM) is in charge of most overseas grants and interestfree loans, while CEB and CDB provide concessional and non-concessional loans and export credits. The Ministry of Finance (MOF) carries out debt relief and channels contributions to multilateral institutions. Finally, the Ministry of Foreign Affairs (MOFA) reviews project requests from partner countries and coordinates related diplomatic efforts. The complexity of this arrangement, the differences in categorical definitions, and the scarcity of official data make it difficult to ascertain the true scope of Chinese development cooperation. Ghin (2012) estimates that China is somewhere between the first and third provider of bilateral assistance. The perceived opacity of Chinese cooperation has triggered debates about China's level of transparency, particularly in the light of the OECD 'aid effectiveness' agenda. Grimm, Rank, McDonald and Schickerling (2011) argue that, although the Chinese government tends to publish less data and statistics than OECD donors, it has been moving towards greater transparency - as reflected in the issuing of cooperation policy white papers. ${ }^{5}$

\section{In January 2007, Prime Minister Wen Jiabao} announced that the CBD and CEB - along with the Agricultural Development Bank of China would become commercial entities. The transition has been slow, partly because these banks played a key role in expanding the domestic economy after the onset of the global crisis, making the government more hesitant to increase these institutions' autonomy. Nevertheless, over the past few years CDB has expanded its cooperation portfolio to encompass partnerships with governments and companies from over 140 countries. It currently has 38 branches and three offices abroad (Cairo, Moscow and Rio de Janeiro) and has become, by some measures, the world's largest development bank. The GEB provides more financing to developing countries than the World Bank. In Africa alone, China has invested over US $\$ 2.4$ billion in infrastructure and commercial projects, mineral resources, machinery manufacturing, power generation and agricultural projects. Through the Forum on China-Africa Cooperation (FOCAC), established in 2000, China has doubled its pledges of cooperation to African partners at each meeting: from US $\$ 5$ billion in 2005 , to US $\$ 10$ billion in 2009 , to US $\$ 20$ billion in 2012. 
Although China often provides highly visible projects, including stadiums, hospitals, and government buildings as part of its soft power strategy, the bulk of its loans is channelled into large-scale infrastructure such as roads, ports, and dams. This focus evokes the Bretton Woods Institutions' early years, when the World Bank and the IMF financed heavy infrastructure; and it contrasts with Northern donors' current prioritisation of social programmes and meeting statistical objectives such as the Millennium Development Goals. In addition, whereas Northern aid has been closely associated with trade liberalisation and financial deregulation, China's cooperation is heavily influenced by the close interlinking of state and market that has characterised Chinese development at home, including regulated trade and financial markets (Mwase and Yang 2012).

China's trade and investment relations with other developing countries have increased dramatically, with China mostly importing raw materials and exporting finished goods. For commodities exporting countries, these exchanges have boosted local economies. In addition, Chinese investment has become an essential source of capital, particularly in the light of widespread disillusionment regarding Northern aid models and lingering bitterness at the structural adjustment packages imposed in the 1980s and 90s (Moyo 2009). As part of a broader wave of South-South cooperation, China has contributed to the advent of an 'age of choice' in which lowincome countries that once depended heavily on Northern aid can now choose among a variety of options (Greenhill, Prizzon and Rogerson 2013; Mohan and Lampert 2013).

Critics of Chinese cooperation sometimes argue that partners are incurring an unhealthy dependency on China, and that the exchange patterns bear an uncanny resemblance to those established during colonial times. Others bemoan the impact of Chinese cooperation on human rights, the environment and labour conditions. Both ends of the spectrum - romantic and doomsday visions of Chinese cooperation tend to overlook its variability: the dynamics and impact of Chinese cooperation have neither been uniform across contexts, nor constant across time (Alden 2008). Although some large-scale infrastructure projects have generated political tensions and social unrest, at other times
Chinese companies have adapted or pulled out of projects altogether, either by choice or due to local resistance. The China National Petroleum Corporation (CNPG), China's largest oil company, revised an oil project in the eastern jungle of Peru after its plans raised environmental and social controversies (Matisoff 2012). Although far from universal, the case reflects a degree of institutional learning by Chinese cooperation entities, as well as the institutions and societies with which they interact. Although the Chinese government may not always have the capacity or political willpower to curb excesses committed by Chinese companies (even those backed by state efforts), it seems keenly aware that funding major infrastructure and industrialisation projects abroad brings the risk of triggering social discontent and political backlash.

\subsection{Moving beyond bilateralism}

Although China has carried out its development cooperation primarily through bilateral channels, over the past decade China has also contributed to multilateral efforts, seeking to become a more active and legitimate multilateral participant as part of a shift towards a more flexible, varied diplomacy. Pessimists view China's multilateralism as a mere façade, whereas optimists see it as reflecting China's commitment to international organisations and peaceful development - arguing that, the more China is incorporated into pre-existing institutions, the easier it will be to 'socialise' Chinese political elites into Northern norms of cooperation (Guogang and Landsdowne 2008). Whereas China exhibited a purposeful yet tentative experimentation with multilateralism in the 1970s and 80s - captured by the Chinese phrase 'crossing the river by feeling for stones ${ }^{9}$ more recently Chinese political elites made significant strides towards enhancing China's multilateralism. At any rate, the idea that China can be 'socialised' into existing norms presupposes a one-way process and underestimates the extent to which China itself influences the multilateral forums in which it participates (Woods 2008).

Although China joined the United Nations in 1971, for the next few decades China remained a largely passive player; for instance, it rarely exercised its veto power within the UNSC. After the start of economic reforms, China has become 
a more visible actor in institutions and regimes, in sectors as varied as financial governance, development and security. By 2007, China expanded its membership from a single intergovernmental organisation (IGO) and 58 NGOs to 49 IGOs and 1,568 NGOs. In addition, it joined a variety of forums and ad hoc negotiations in areas including arms control and climate change (Kent 2007). China's 2011 accession to the World Trade Organization (WTO) was a major turning point in its multilateralism: China was inducted only after the government proved willing to impose significant changes to the Chinese economy, including industrial policies and tariff reductions. Although, as a P5 country, China is hesitant to reform certain aspects of the global governance system, China's highly variable behaviour within multilateral institutions is not easily captured by dichotomies between 'status quo' and 'revisionist' (Wuthnow, Li and Qi 2012).

China has drawn on a variety of strategies to boost its multilateral diplomacy. First, it has increased its contributions towards, and its activism within, UN agencies and other established organisations. In some instances, these contributions have translated into enhanced influence within organisations. For instance, in April 2010, the World Bank agreed to expand China's voting power above those of several Western powers, including Germany, France and Britain, elevating China to behind only the USA and Japan in the 186-nation lending organisation. In terms of voting power, China's stake in the World Bank increased from 2.78 per cent to 4.42 per cent (the USA has 15.85 per cent, and Japan has 6.84 per cent) (RTHK 2010). Second, more Chinese citizens began occupying senior positions in major institutions, including the United Nations, the World Health Organization, the WTO and the World Bank. Taiwan-born Justin Yifu Lin, who defected to mainland China and became an economics professor at Peking University, served as chief economist and senior vice president of the World Bank from June 2008 to June 2012.

In addition, China has begun spearheading or co-launching new multilateral initiatives. Over the past decade, it has helped to consolidate the Shanghai Cooperation Organisation (SCO), originally started in 1996. The SCO originally focused on its member states' security concerns in Central Asia, but China has assumed a leadership position in deepening and broadening the SCO's mandate towards economic and development cooperation initiatives (Jia 2007). China was also instrumental in the creation of the Boao Forum for Asia (BFA), an NGO modelled on the World Economic Forum and designed to bring together business, government and academic leaders for strategic discussions.

Aside from these regional initiatives, China has been an active participant and/or founding member of coalitions such as the G20 and (as examined in greater detail in Section 3.3) the BRICS. Through these platforms, Chinese diplomats now regularly meet with their counterparts on the sidelines of major international meetings, including those of the UN General Assembly and the IMF. China has been hosting more high-level meetings, such as the 2011 BRICS Summit, held in Sanya. Through this burgeoning multilateralism - the result of incremental changes rather than a conscious policy - China has honed its diplomatic skills, acquiring the knowledge and negotiation styles needed to manage multilateral cooperation. From a mere follower of rules, in many areas China has begun to play a proactive role in the setting of global agendas and in multilateral institutionbuilding (Shen 2008). Through these strategies, China works to legitimise itself as a global player, including - as the next section shows - in the field of international development.

\subsection{China's role in multilateral development banks}

China's participation in the BDB project would be far from its first engagement with a multilateral development financing institution. China joined the World Bank in 1980 (Bretton Woods Project 2011), although for a decade it remained a minor player, borrowing from the bank's low-income country branch. Nowadays, China is classified by the World Bank as a middle-income country, and the Chinese government essentially uses the institution's loans only for small-scale projects. However, China has begun participating in the bank's policy debates; in 2012, for instance, the Development Research Centre (DRG) of the PRC State Council teamed up with the World Bank to produce a 468-page report, titled 'China 2030', that establishes a wide range of policy measures to prevent China from falling into the 'middleincome trap' (The Economist 2012). In 2013, Premier Li Keqiang stated that China was willing 
to collaborate more closely with the World Bank, and he called upon the institution to 'play a bigger role in assisting developing countries and in poverty reduction' (Xinhua 2013).

Ghina has also joined a variety of regional development banks. In Asia, it has been a part of the Asian Development Bank (ADB) since 1986 and currently holds the third largest proportion of shares (after the USA and Japan). China's geopolitical interests have occasionally shaped ADB initiatives. In 2009, after the bank announced US $\$ 2.9$ billion for projects in India, China's MOFA strongly condemned the move, voicing concern over a US\$60 million watershed protection project in the Arunachal Pradesh region, where part of the China-India territorial dispute is located (SINA 2009). Although in 2010, when Premier Wen Jiabao visited India, the two sides signed an agreement on India-China Border Affairs, recurring territorial tensions led the Indian government to announce in 2013, unilateral plans to develop the region without loans from the ADB (Wu 2013; African Development Bank n.d.). The case illustrates some of the conflicts of interest that may emerge within a BDB, particularly where geopolitical rivals China and India are concerned.

Over the past decade, as its interests have expanded beyond Asia, China has significantly stepped up its activism within multilateral development initiatives beyond Asia. In the mid1980s, China joined the African Development Bank (AfDB) and the African Development Fund (ADF). Since then, China has signed agreements in areas including environment, agriculture, water and health, and both CEB and the CDB signed new Memoranda of Understanding with the AfDB. China's contribution to the AfDB alone has increased from an initial US\$14.59 million to a total of US $\$ 486$ million. More recently, China has been discussing a new co-financing mechanism to fund infrastructure and private sector initiatives in Africa (African Development Bank n.d.). Given the BDB's probable initial focus on Africa, these precedents mean that Chinese bank officials have acquired considerable knowledge and experience interfacing with the region's major development institutions, as well as individual state governments.

China's engagement with development financing abroad has also generated some innovations that may prove relevant to the $\mathrm{BDB}$. China is a member of the Inter-American Development Bank (IADB), contributing US\$250 million to various programmes since 2009. In 2013 the People's Bank of China (PBC) announced it would provide $\$ 2$ billion to a Co-financing Fund for projects related to poverty alleviation, inequality reduction, private sector investment, social welfare, climate change and gender equality (IADB 2013). This type of joint financing, reaching far beyond China's typical investments in heavy infrastructure, may be a way to channel Chinese capital to sectors prioritised by regional institutions, provided that the BDB has mechanisms for such arrangements in the future.

As for the normative aspect of development multilateralism, China's engagement with the OECD and particularly the DAC has been marked by a pronounced ambivalence. Like the other BRICI, China is not a member of the OECD and has largely rejected the DAC's attempt to codify the norms and practices of international aid. In 2011, for the first time, Chinese representatives (along with those from Brazil, India, Indonesia and South Africa) attended the DAC senior-level meeting of directors-general (Eyben 2012). During the Fourth High Level Forum on Aid Effectiveness, held in Busan, South Korea, negotiators from the DAC member states argued that countries like China, Brazil and India should make commitments to making their cooperation more measurable, transparent and efficient. DAC donors made persistent efforts to engage with China and refined the final document specifically in order to persuade China to sign, adding the option of voluntary standards for nonDAC members (Barder 2011; Mawdsley, Savage and Kim 2012). Several non-DAC members ended up agreeing to voluntary standards while insisting that South-South cooperation should not be subject to the same expectations as Western aid (Strange et al. 2013). Overall, the BRICS countries did not adopt a coordinated approach: while Brazil was content to sign the document, India proved reluctant, and Russian representatives distanced themselves from both China and Brazil (Eyben and Savage 2012). Other than the China-DAC Study Group, which brings together Chinese and foreign cooperation and aid experts for discussions on development issues, China has little interface with the DAC. 
China's resistance to DAC-led efforts, shared to some degree by the other BRICS, seems to carry over into its role in post-2015 development goals. Within these discussions, China has stressed the importance of poverty alleviation and the need to address development in Africa, and it has insisted that the new agenda must accommodate different models of development - in essence, suggesting it will resist the formulation of rigid normative frameworks. As China's role in the post-2015 debates shifts from a mostly reactive stance to a more proactive position (Wheeler 2013), these viewpoints will no doubt influence the practices and normative stances established by the BDB. While China's stress on poverty alleviation will ensure that the objective features prominently among the bank's overarching goals, the institution is unlikely to adopt norms regarding transparency, impact evaluation and efficacy as defined by the DAC. Insofar as the bank constitutes a concrete application of the BRICS' positions on development, including China's steadfast positions, the institution is bound to feature prominently in global debates about development norms. Accordingly, contestation of the BDB, already voiced by a number of scholars and civil society entities (see Yu 2013; Dossani 2014), is likely to sharpen.

\section{Conclusion}

Although China does not need the BDB as a way of boosting its cooperation portfolio (massive by any measure) its participation in the initiative generates a series of benefits for China, most of them political. In the light of the Chinese government's drive to boost its multilateral diplomacy and to project the image of a responsible, peace-loving country, the bank initiative offers an opportunity for China to engage with other rising powers on a concrete initiative of high visibility. Although China already cooperates with development finance institutions around the world, the bank will mark the first time that China becomes a founding member of an organisation dedicated exclusively to boosting South-South development cooperation.

At the same time, the size of China's economy and its global projection have prompted anxiety about China dominating the BRICS.

Economically, after all, the grouping is not one of equal parties; the volume of trade and financial transactions between each country and China far exceeds any other bilateral cooperation tie within the grouping (Russkyi Mir Foundation 2013). Moreover, China's cooperation with other developing countries outpaces that of any of the other BRICS. This asymmetry has led some critics to argue that the BRICS is nothing more than a platform for China's rise. This view tends to underestimate the extent to which Chinese policy elites endeavour to transform China into a legitimate multilateral player aligned with other rising powers. Becoming hegemonic within the grouping would in fact run counter to China's long-term interests.

This does not mean that, when experts sit down to hammer out credit lines and loan conditions, China's interests will fade into the background. The characteristics of Chinese development cooperation - including its vast experience abroad, its agility, and its claim to successful implementation of infrastructure and industrialisation projects - may incrementally pressure the BDB towards certain directions. In the long term, the degree of the tilt will depend on how well the decision-making structures built into the bank's design reflect an equitable distribution of influence (for instance, through equal voting rights and/or, in the case of China, a cap on contributions).

As for how China will approach the negotiating table during the bank's design process, a representative from one of China's key development financing institutions affirms that China's practice of providing loans based on projects must be maintained, even when there is regime change: 'A project is a project. So long as that project is commercially viable and eventually proves beneficial to the social wellbeing of that country, then we will go ahead [with the loan]. This new institution has to work along the same lines.' Given how strongly other BRICS states' foreign policies have emphasised the concept of national sovereignty, this preference is unlikely to meet with resistance even from democratic Brazil, India and South Africa.

As for its substantive contribution to the bank project, China's discourse regarding poverty alleviation must reach beyond generic statements about the economic benefits of heavy infrastructure. In the 1960s and 70s, when the Bretton Woods Institutions focused on heavy infrastructure, its leaders relied on a vague trickle-down economics to justify medium and 
large projects: the idea was that building a $\mathrm{dam} / \mathrm{road} /$ port would increase output, generate jobs and foster growth that would benefit the population more broadly. The impact of such projects, including on local and regional patterns of poverty, turned out to be more complicated, with population displacement and social tensions emerging alongside pockets of prosperity. The same has been true of many projects financed by the individual BRICS. Within the BDB, China must therefore join forces with fellow member states to find innovative ways to link infrastructure and industrialisation with poverty alleviation. Otherwise, the bank runs the risk of throwing back cooperation to the era when economic growth was used as a narrow proxy for development - an outlook that would do tremendous disservice to low-income countries.

China's impact on the BDB may be felt just as much by what is kept off the table as what is maintained on the bank's agenda: concern for human and labour rights, environmental conditions, and other dimensions of social wellbeing. Another missing element will be civil society entities. Although NGOs, professional organisations and diaspora community institutions have become key participants in some of the BRICIS states' individual cooperation programmes, especially those of Brazil and India,

\section{Notes}

* Institute of International Relations of the Pontifical Catholic University of Rio de Janeiro, PUC-Rio/BRICS Policy Center.

1 The author wishes to thank the Fundação de Amparo à Pesquisa no Estado do Rio de Janeiro (FAPERJ), the Jovem Cientista programme, CAPES and DFID for supporting this research.

2 P5 refers to the five members of the UN Security Council: China, France, Russia, the UK and the USA.

3 Russia does not adopt the language of 'developing country', although neither does it it is unlikely that the BDB will grant them space for participation or contestation, in part due to Chinese (and Russian) fears of political contestation. Finally, from the perspective of the bank's potential loan recipients, the bank will probably bring a mixed bag of benefits and risks. BDB loans will further broaden the range of financing options available to low-income countries, contributing to the so-called 'age of choice', but it may also end up subjecting them to new norms and practices altogether. The Busan meeting showed quite clearly that - far from China being passively 'socialised' into DAC norms, global debates and practices are themselves also influenced by China's rejection of Western normative frameworks.

While the BRICS have not yet offered a coherent set of development cooperation norms, the bank project may present those five countries with an occasion to find common ground, precisely at a time when the post-2015 development discussions is reshaping the global development agenda. China should apply its experiences with development - both at home and through the lessons learned financing projects abroad - to the BDB without losing sight of overarching goals such as poverty alleviation and contributing to the wellbeing of populations in low-income countries.

see itself as a Northern donor. In addition, Russia is not part of the OECD.

4 The grouping has also agreed upon a reserve pooling arrangement, with US $\$ 100$ billion set aside to counter crises, as well as the impact of withdrawal of stimulus by the US Federal Reserve.

5 Key documents include: China's African Policy (January 2006), China-Africa Economic and Trade Cooperation (December 2010), China's Foreign Aid (April 2011) and China-Africa Economic and Trade Cooperation (August 2013).

6 Pinyin: Mozhe shitou guohe. 


\section{References}

African Development Bank (n.d.) 'China Partnership Overview’, African Development Bank Group, www.afdb.org/en/topics-and-sectors/ topics/partnerships/non-regional-membercountries/china/ (accessed 1 February 2014)

Alden, C. (2008) China in Africa, London: Zed Books

Arkhangelskaya, A. and Shubin, V. (2013) Russia-South Africa Relations: Beyond Revival, SAIIA Policy Briefing 75, Global Powers and Africa Programme, Johannesburg: South African Institute of International Affairs

Bakalova, E. and Spanger, H.-J. (2013) Development Cooperation or Competition? Russia as a Re-Emerging Donor, PRIF Report 123, Frankfurt: Peace Research Institute

Barder, O. (2011) 'What Happened in Busan?', Owen Abroad, blog, 11 December, www.owen.org/ blog/5131 (last accessed March 2014)

Besharati, N. (2013) 'The Establishment of the South African Development Partnership Agency: Institutional Complexities and Political Exigencies', South African Journal of International Affairs 20.3: 357-77

Brautigam, D. (2009) 'China's Challenge to the International Aid Architecture', World Politics Review 1.4: 1-10

Bretton Woods Project (2011) 'China and the World Bank', Bretton Woods Project, 14 September, www.brettonwoodsproject.org/2011/09/art568894/ (accessed 1 February 2014)

BRICS (2013) eThekwini Declaration, Fifth BRICS Summit, Durban, 27 March

Cabral, L. and Weinstock, J. (2010) Brazilian Technical Cooperation for Development: Drivers, Mechanics and Future Prospects, ODI Report, London: Overseas Development Institute Caulderwood, K. (2014) 'BRICS are Making their Own Development Bank, but it's not Going to be Simple', International Business Times, 25 February, www.ibtimes.com/bricsare-making-their-own-development-bank-itsnot-going-be-simple-1557617 (last accessed March 2014)

Chin, G. (2012) 'China as a Net Donor: Tracking Dollars and Sense', Cambridge Review of International Affairs 25.4: 579-603

China Development Bank (n.d.) China Development Bank, Beijing: www.cdb.com.cn/english/ Column.asp?ColumnId $=96$ (accessed 1 February 2014)

Dossani, S. (2014) 'BRICS Bank: New Bottle, How's the Wine?', Bretton Woods Bulletin,
27 February, www.brettonwoodsproject.org/ 2014/02/brics-bank-new-bottle-hows-wine/ (accessed 1 February 2014)

Eyben, R. (2012) 'Struggles in Paris: The DAC and the Purposes of Development Aid', European Journal of Development Research 25.1: 78-91

Eyben, R. and Savage, L. (2012) 'Emerging and Submerging Powers: Imagined Geographies in the New Development Partnership at the Busan Fourth High Level Forum', Journal of Development Studies 49.4: 457-69

Gallagher, K. (2013) 'China's Development Banks Need to Clean Up Their Act', Poverty Matters Blog, 10 July, www.theguardian.com/ global-development/poverty-matters/2013/jul/ 10/china-development-banks-environment (accessed 1 February 2014)

Greenhill, R.; Prizzon, A. and Rogerson, A. (2013) The Age of Choice: Developing Countries in the New Aid Landscape, ODI Working Paper 364, London: Overseas Development Institute Grimm, S.; Rank, R.; McDonald M. and Schickerling, E. (2011) Transparency of Chinese Aid: An Analysis of the Published Information on Chinese External Financial Flows, Stellenbosch: Centre for Chinese Studies, University of Stellenbosch

Guogang, W. and Landsdowne, H. (2008) China Turns to Multilateralism: Foreign Policy and Regional Security, London: Routledge He, W. (2011) 'When BRIC Becomes BRICS: The Tightening Relations between South Africa and China', East Asia Forum, 3 March, www.eastasiaforum.org/2011/03/03/when-bricbecomes-brics-the-tightening-relationsbetween-south-africa-and-china/ (accessed 1 February 2014)

IADB (2013) 'China to Provide $\$ 2$ Billion for Latin America and the Caribbean Co-financing Fund', Inter-American Development Bank, 16 March, www.iadb.org/en/news/newsreleases/2013-03-16/china-co-financingfund,10375.html \#.Umz8oyQYKS4 (accessed 1 February 2014)

Jia, Q. (2007) The Shanghai Cooperation Organisation: China's Experiment in Multilateral Leadership, Slavic Research Center Paper, June, Sapporo, Japan: Slavic Research Center Kahler, M. (2013) 'Rising Powers and Global Governance: Negotiating Change in a Resilient Status Quo', International Affairs 89.3: 711-29

Kent, A. (2007) Beyond Compliance: China, International Organisations and Global Security, Stanford: Stanford University Press 
Matisoff, A. (2012) Exploring Civil Society

Engagement with Chinese Companies Abroad: The China National Petroleum Corporation in Peru, Yale School of Forestry and Environmental Studies, http://environment.yale.edu/tri/fellow/1612[0]/ (accessed 1 February 2014)

Mawdsley, E. (2012) From Recipients to Donors: Emerging Powers and the Changing Development Landscape, London: Zed Books

Mawdsley, E.; Savage, L. and Kim, S. (2012) 'A "Post-Aid World"? Paradigm Shift in Foreign Aid and Development Cooperation at the 2011 Busan High Level Forum', The Geographical Journal 2013: 1-12

Meng, J. and Sun, Y. (2013) 'Chinese NGOs Reach Out to African Countries', China Daily, 29 April, http://english.peopledaily.com.cn/ 90883/8228058.html (accessed 1 February 2014)

Mohan, G. and Lampert, B. (2013) 'Negotiating China: Reinserting African Agency into ChinaAfrica Relations', African Affairs 112.446: 92-110

Moyo, D. (2009) Dead Aid: Why Aid is Not Working and How There is a Better Way for Africa, Vancouver: Douglas \& McIntyre

Mwase, N. and Yang, Y. (2012) BRICs' Philosophies for Development Financing and Their Implications for LICs, IMF Working Paper, Washington DC: International Monetary Fund

Naím, M. (2007) 'Rogue Aid', Foreign Policy, 1 March, www.foreignpolicy.com/articles/2007/ 02/14/rogue_aid (accessed 1 February 2014)

Naughton, B. (2007) The Chinese Economy: Transitions and Growth, Cambridge MA: MIT Press

OECD (2012) Development: Aid to Developing Countries Falls Because of Global Recession, Organisation for Economic Co-operation and Development, 4 April, www.oecd.org/newsroom/ developmentaidtodevelopingcountriesfalls becauseofglobal recession.htm (last accessed March 2014)

Office of the State Council (2013) China-Africa Economic and Trade Cooperation, White Paper, 29 August, http://news.xinhuanet.com/ english/china/2013-08/29/c_132673093.htm (accessed 1 February 2014)

Provaggi, A. (2013) China Development Bank's Financing Mechanisms: Focus on Foreign Investments, Global Projects Center Paper, May, Stanford: Stanford University, https://gpc.stanford.edu/sites/default/files/ uc07_0.pdf (accessed 1 February 2014)

Radebe, H. (2012) 'BRICS a Force for World Peace, Says China', Business Day BDlive,
8 August, www.bdlive.co.za/articles/2012/03/ 28/brics-a-force-for-world-peace-says-china; jsessionid =FE12752397A285D7F7DBD3905 C73C17A.present1.bdfm (accessed 1 February 2014)

Raghavan, P.S. (2013) 'Mapping Experiences around International Cooperation: New Challenges and Opportunities', text of the speech of Mr P.S. Raghavan, Additional Secretary, DPA, Ministry of External Affairs at Round Table, Observer Research Foundation, New Delhi, 5 March, www.observerindia.com/ cms/export/orfonline/documents/ospeech.pdf (accessed 1 February 2014)

RTHK (2010) China Given More Influence in World Bank, 26 April, www.rthk.org.hk/rthk/news/ englishnews/news.htm?main\&20100426\&56\& 663699 (accessed 1 February 2014)

Russkyi Mir Foundation (2013) Can BRICS Unite on Global Issues?, 3 July, www.russkiymir.ru/ russkiymir/en/brics/articles/article0005.html (accessed 1 February 2014)

Shen, W. (2008) In the Mood for Multilateralism? China's Evolving Global View, Gentre Asie IFRI Working Paper, July, Paris: Institut Français des Relations Internationales

SINA (2009) China Slams ADB Over India Funding, SINA, 9 June and 19 May, http://english.sina.com/china/2009/0618/ 249531.html (accessed 1 February 2014)

Strange, A.; Parks, B.; Tierney, M.; Fuchs, A.; Dreher, A. and Ramachandran, V. (2013) China's Development Finance to Africa: A MediaBased Approach to Data Collection, Center for Global Development Working Paper 323, Washington DC: Center for Global Development

The Economist (2012) 'China and the World Bank: 2030 Vision', 28 February, www.economist.com/ blogs/analects/2012/02/china-and-world-bank (accessed 1 February 2014)

Ventures Africa (2013) \$1B China-Lusophone Africa Development Fund Set Up, 28 June, www.ventures-africa.com/2013/06/1b-chinalusophone-africa-development-fund-set-up/ (accessed 1 February 2014)

Vickers, B. (2012) 'Towards a New Aid Paradigm: South Africa as African Development Partner', Cambridge Review of International Affairs 25.4: 535-56

Wheeler, T. (2013) 'A Reluctant Leader? China and Post-2015', Saferworld, 14 November, www.saferworld.org.uk/news-and-views/ comment/117 (accessed 1 February 2014) 
Woods, N. (2008) 'Whose Aid? Whose Influence? China, Emerging Donors and the Silent Revolution in Development Assistance', International Affairs 84.6: 1205-21

Wright, C. (2013) 'BRICS Urged to Build Formal Structure', Emerging Markets, 10 September, www.emergingmarkets.org/Article/3265011/ News/BRICS-urged-to-build-formalstructure.html (accessed 1 February 2014)

Wu, Z (2013) 'Complex Issue, Hopeful Prospects', Beijing Review, 9 September, www.bjreview.com.cn/Cover_Story_Series/ 2013-09/09/content_568528.htm (accessed 1 February 2014)

Wuthnow, J.; Li, X. and Qi, L. (2012) 'Diverse Multilateralism: Four Strategies in China's Multilateral Diplomacy', Journal of Chinese Political Science 17.3: 269-90
Xinhua (2013) Li: China to Deepen Collaboration with World Bank, 19 September, Xinhua, http://news.xinhuanet.com/english/video/2013 -09/18/c_132730219.htm (accessed 1 February 2014)

Yu, C. (2013) 'Be Careful, BRICS Development Bank', Our World, United Nations University, 22 July, http://ourworld.unu.edu/en/be-carefulbrics-development-bank (last accessed March 2014)

Zhao, M. (2013) 'China's Pivotal BRICS Strategy', The BRICS Post, 10 October, http://thebricspost.com/ chinas-pivotal-bricsstrategy/\#.Ulqf9WS9Kc0 (accessed 1 February 2014) 